\title{
The methodology of content and language integrated learning (CLIL) in modern methodical and scientific literature of native and foreign scholars
}

\author{
I. V. Shevchenko, O. M. Kordyuk \\ V.O. Suhkomlynsky National University of Mykolaiv, Mykolaiv, Ukraine \\ Corresponding author. E-mail: shevchenko2011@gmail.com
}

Paper received 20.04.18; Accepted for publication 26.04.18.

\section{http://doi.org/10.31174/SEND-PP2018-163VI67-12}

\begin{abstract}
The article is dedicated to the problem of content and language integrated learning (CLIL) in modern methodical and scientific literature of native and foreign scholars. The notion CLIL is explained, the analysis of scholars' views regarding advantaged of using content and language integrated learning when studying a foreign language is presented. Advantages and disadvantaged of the presented methodology are pointed out. The main advantages of CLIL methodology are encouraging to study a foreign language, the development of creative mental abilities of learners, purposeful mastering of lexical units by them. The importance of the presented methodology is in the fact that learners acquire knowledge in other subjects which that will use in their future professional activity.
\end{abstract}

Keywords: content and language integrated learning, motivation, mental abilities, native and foreign scholars, foreign language competence.

Problem statement. In contemporary conditions of integration, globalization and technological development of the society speaking a foreign language is becoming especially important, because there is the necessity of communication with representatives of other cultures. The experience shows that speaking the foreign language is not always enough. One must possess integrated communicative skills of communication, which will enable professional and business communication between people of different countries.

In this respect, a special attention in the context of functional mastering the foreign language and the principle of integrity, is being given to CLIL methodology that is known all over the world and has been actively used with the purpose of effective foreign language learning.

The term CLIL (Content and Language Integrated Learning) was used by the scholar David Marsh in 1994 to define the methodology of teaching and learning comprehensive subject by means of a foreign language.

D. Marsh explains that CLIL considers studying a foreign language as a means of mastering other subjects, which arises in learners the need to study and allows him to reconsider and develop different communicative skills, including those in their native language.

In contemporary methodological literature CLIL is explained as the methodology that allows forming in learners a foreign language linguistic and communicative competence, including the one in learning context, in which there happens the formation of general knowledge and skills. Using of CLIL methodology presupposes studying non-language subjects (biology, mathematics, geography, etc) by means of foreign languages [7].

Analysis of contemporary researches and publications. Such scholars as S. Bobil, Yu. Roudnik, Yu. Sobol and others focused their attention on the problem of content and language integrated learning.

Among foreign researchers of the problem of content and language integrated learning we could point out $\mathrm{M}$. Allen, A. Bonne, D. Greddol, L. Collins, D. Marsh, I. Ting and many others.

Purpose of the article. To analyze in methodological and scientific literature views of contemporary scholars regarding the usage of CLIL methodology with the purpose of studying a foreign language, to point out advantages and disadvantages of the presented methodology.

Presentation of the principal material. Nowadays the use of CLIL methodology is mostly spread in the countries of the Western Europe (Belgium, France, Germany and others). Besides, the mentioned methodology is used in Spain, Estonia, Poland, Lithuania, Italy, Finland, the Czech Republic and other countries of the world. The peculiarities of realization CLIL methodology in different countries depend on a selected model. Thus, there are three CLIL models: soft (languageled), hard (subject-led), partial immersion. The first model is directed to linguistic peculiarities of a special context, the second one means that $50 \%$ of the curriculum special subjects are studied in a foreign language, the third one takes the middle position and is used when some of the modules from the speciality programme are studied in a foreign language $[2 ; 3]$.

In many scholars' opinion, the important basic point for accepting CLIL methodology is the recognition of the fact that every learner is a clever and educated personality, who can demonstrate his intellect sometimes only in his native language. Very often, spearing in the situation which requires speaking a foreign language, they turn out to be unable to show their knowledge in branches of specific knowledge - economy, medicine, mathematics, etc. Without knowledge of a foreign language for those branches they have no possibility to communicate in the professional context. Besides, learners can be limited in approaching informational resources with specialties which they need and they have no opportunity for an effective professional growth. Profilisation in teaching a foreign language will make it possible to diverge from the ordinary contexts such as "My Family", "Seasons and Weather" and others, turn to communicative situations which are typical for further professional and universal communication of learners. Therefore, the functional approach to teaching a foreign language enables to achieve even a greater effectiveness by means of proposal of a broad mainstream context as an educational process. 
According to the professor Rosa Munoz-Luna from Columbia Central University the interrelation of the content and learning languages has become a general practice of European higher education. CLIL is a result of the recent European policy directed to learning other languages in natural conditions. In this general European context every EU country underwent historical factors which caused the formation of contemporary educational situations in a language.

In the scholar's opinion, CLIL is a natural and necessary result of a paradigmatic and pedagogical evolution in teaching a foreign language. Language forms and structures have given way to the context, placing communicative purposes as the basis of a language teaching [9].

From the pedagogical perspective, cramming and revising have been gradually replaced by contextual language interactions in which learners must find and build their own reports. In such a constructive surrounding tasks of teachers inevitably broaden. Now their responsibility is in defining learners' needs and strategies of teaching to provide them with contextual information.

On learners' side, they are autonomous, though it does not mean that they use cognitive strategies for having an opportunity to modify their own rhythms of learning.

Thus, traditional methods of teaching a language have been disturbed. The chief position is occupied by the cohesive and comprehensive CLIL methodology that corresponds to constructivism and contains numerous methods and interdisciplinary concepts.

The advantages of the presented methodology are as follows:

- Learners work on the basis of the previously acquired knowledge with the purpose of mastering new notions;

- There is a more context learning in which the language and the topic content are wholly integrated [9].

Scholar O. Khodakovska believes that learning a language becomes more purpose-oriented as the language is used for solving particular communicative tasks. Besides, learners have the opportunity to become better acquainted and get deeper understanding of the culture of the language they study which will lead to formation of learners' social-cultural competence.

However, scholar M. Hajer entertains the idea that the content-integrated learning results in decreasing the content competence or imperfect understanding of the subject by learners, because teacher make the content of the curriculm easier in advance [5].

A learner internalizes quite a massive volume of language material that has the form of complete immersion into the natural language surrounding. Working with different terms gives the possibility to learn specific terms, certain language constructions, which encourages enriching learners' vocabulary with the subject terminology and prepares him for further study and implementation of the acquired knowledge and skills. Studying a foreign language and a non-language subject simultaneously is an additional means of achieving educational goals and has positive sides both for studying then foreign language and the non-language subject [4].
Scholar Gerhard Vollmer states that linguistic problems, which participants of the content and language integrated learning face, quite often activate learners' creative mental activity (by means of working out the details of the situation and pointing out contradictions), in such a way a deeper semantic processing of words and understanding of the curriculum concepts by the learners can happen [8].

According to A. Bonnet, learners can wholly skip into a foreign language when a conceptual problem occurs, but this ability does not help to solve the language problem. What might be an obstacle for a learner, in fact becomes a strong potential for him, in particular, for learning subject definite notions. It should be mentioned that learners involved into the content and language integrated learning may appear to find out themselves in unfavorable condition on the exams in different subjects, excluding integrating ones, such as foreign language and native language or literature [8].

Scholar O. Kochenkova believes that in this case CLIL methodology is based on the inner motivation, namely, learners are involved into interesting and meaningful activities, herewith using the language. Learning a language comes along with everything happening in the classroom and meets all relevant needs. In other word, CLIL gives a great number of opportunities for involuntary language learning; the learning which happens when learners' attention is focused on something else, not what they are studying. Such involuntary language learning turned out to be very effective, profound and long lasting. It effectively complements deliberate language learning which, as a rule, is observed on a traditional foreign language class. In fact, CLIL is not meant to full replacement of the traditional language learning, and using its elements is real and rational in the conditions of contemporary Ukrainian education [1].

Thus, the scholar considers that CLIL methodology is:

- an educational approach that supports language variety and is a powerful instrument that can have a significant influence on learning the language in the future;

- an innovative approach to study, dynamic and motivational force with cohesive structure. It represents the attempt to overcome limitations of traditional curricula, i.e. learning separate subjects, and it tends to educational integration;

- realization of study in different forms and situations; it may concern the whole year of teaching one or several subjects, for instance, biology, history, mathematics, or learning a module on a particular topic or as a part of a regular course;

- it is meant to improve foreign language competence and develop knowledge and skills of certain subjects [1].

Conclusions and proposals. Contemporary CLIL methodology has apparent advantages in the process of a foreign language study. It motivates learners' studying, activate their creative mental activity, encourages their comprehensive remembering new lexical units, learning grammar rules, directs to improving a foreign language competence and developing knowledge and skills of certain subjects with the purpose of using them in future professional activity. 


\section{ЛИТЕРАТУРА}

1. Коченкова О. Возможности профилизации преподавания иностранных языков с помощью применения элементов методики CLIL (интегрирование преподавания иностранного языка и других учебных дисциплин) [Електронний ресурс] / О.М. Коченкова // Режим доступу:

http://kochenkova.ru/publ/vozmozhnosti_profilizacii_prepoda vanija_inost

vozmozshnosti_profilizatsii_rannykh_jazykov_s_pomoshhju _primenenija_ehlementov_metodiki_clil_integrirovanie_prep odavanija_inostrann/1-1-0-1 - Назва 3 екрану.

2. Крашенинникова А. К вопросу об использовании предметно- языкового интегрированного обучения CLIL [Електронний ресурс] /А.Е. Крашенникова //- Режим доступу:http://www.rusnauka.com/3_ANR_2013/Pedagogica 15_126661.doc.

3. Руднік Ю. Впровадження методики предметно-мовного інтегрованого навчання : за і проти (світовий досвід) [Електронний ресурс] /Ю.В. Рудник //- Режим доступу: http://elibrary.kubg.edu.ua/2896/1/Y_Rudnik_VOU_13_IM MN_PI.pdf - Назва з екрану.

4. Ходаковська О. Особливості методики предметномовного інтегрованого навчання [Електронний ресурс] / О. Ходаковська // - Режим доступу: https://conf.ztu.edu.ua/wp-content/uploads/2016/11/63.pdf Назва з екрану.

5. Hajer M. Creating a language-promoting classroom: contentarea teacher sat work. In Hall, Joan Kelly and Lorrie Stoops Verplaetse (eds.) /M. Hajer, L.Maaike. - Second and foreign language learning through classroom interaction. Mahwah N.J. and London: Lawrence Erlbaum Associates. - 2000. pp. 265-285.

6. Lorenzo W. E.. Immersioneducation a l'americaine: Adescriptive study of USimmersion programs / W. E.Lorenzo, Gladstein L.A. Foreign Language Annals, 17(1) 1984. - p.p. 35-42.

7. Marsh D. Content and Language Integrated Learning: The European Dimension - Actions, Trends and Foresight Potential / D. Marsh // Retrieved December 18, 2016, [Електронний pecypc]. - Режим доступу: fromhttp://europa.eu.int/comm/education/languages/index/ht ml. - Назва з екрану.

8. Vollmer G. Helmut Johannes, Lena Heine, Randi Troschke, Debbie Coetzee, Verena Kuttel. 2006. Subject-specific competence and language use of CLIL learners: The case of geography in grade 10 of secondary schools in Germany / G. Vollmer, Helmut Johannes, Lena Heine, Randi Troschke, Debbie Coetzee, Verena Kuttel // Paper presented at the ESSE8 Conference in London, 29 August 2006. - pp.22-25

9. Munoz-Luna Rosa. From drills to CLIL: the paradigmatic and methodological evolution towards the integration of content and foreign language/ Rosa Munoz-Luna // Revista PROFILE: Issues in Teachers' Professional $\begin{array}{lll}\text { Development. 16.1 (Apr. } & \text { 2014): } & \text { p167+. }\end{array}$ Copyright: COPYRIGHT 2014 Universidad Nacional de Colombia. [Електронний pecypc]. - Режим доступу: http://www.scielo.org.co/scielo.php?script=sci_serial\&pid=1 657-0790\&nrm=iso - Назва з екрану.

\section{REFERENCES}

1. Kochenkova O. Possibilities of profilisation of teaching foreign languages by means of using the elements of CLIL methodology (integrated teaching of a foreign language and other subjects)/ O.M. Kochenkova // [Electronic resource]. Access mode: http://kochenkova.ru/publ/vozmozhnosti_profilizacii_prepoda vanija_inost vozmozshnosti_profilizatsii_rannykh_jazykov_s_pomoshhju _primenenija_ehlementov_metodiki_clil_integrirovanie_prep odavanija_inostrann/1-1-0-1 - The name from the screen.

2. Krashennikova A.Ye. To the issue of using content and language integrated learning CLIL /A.Ye. Krashennikova// $\begin{array}{llll}\text { [Electronic } & \text { resource]. } & - & \text { Access }\end{array}$

mode:http://www.rusnauka.com/3_ANR_2013/Pedagogica/5 126661.doc.htm - The name from the screen.

3. Roudnik Yu.V. Implementation of content and language integrated learning: pros and cons (world experience) / Yu.V. Roudnik // [Electronic resource]. - Access mode:http://elibrary.kubg.edu.ua/2896/1/Y_Rudnik_VOU_13 _IMMN_PI.pdf - The name from the screen.

4. Khodakovska O. Peculiarities of methodology of content and language integrated learning / O. Khodakovska // [Electronic resource]. - Access mode:

https://conf.ztu.edu.ua/wp-content/uploads/2016/11/63.pdf The name from the screen.

\section{Методика предметно-интегрованого обучения (CLIL) в современной методической и научной литературе отечественных и зарубежных авторов \\ И. В. Шевченко, Е. Н. Кордюк}

Аннотация. Статья посвящена проблеме методики предметно-языкового интегрованого обучения (CLIL) в coвременной методической и научной литературе отечественных и современных авторов. Дается пояснение понятия (CLIL), подается анализ взглядов ученых, касающихся преимуществ использования предметно-языкового интенрованого обучения во время обучения иностранному языку. Обращается внимание на преимущества и недостатки данной методики. Главными преимуществами методики (CLIL) является повышение мотивации изучения иностранного языка, развитие творческих умственных способностей учеников или студентов, целенаправленое выучивание лексических единиц. Значение предложеной методики заключается в том, что ученики или студенты приобретают знания по другим дисциплинам, которые они будут использовать в своей будущей профессиональной деятельности.

Ключевые слова: предметно-языковое интегрованое обучение,мотивація, умственные способности, отечественные и зарубежные авторы, иноязычная компетениія. 